Acta Linguistica Hungarica, Vol. 52 (4), pp. 397-409 (2005)

\title{
ASPECT MARKERS GRAMMATICALIZED FROM VERBS IN KAMAS
}

\author{
GERSON KLUMPP
}

\begin{abstract}
The article presents some results of research into aspectual auxiliaries of Kamas (Southern Samoyed; extinct). Code-copied from Turkic, Kamas started to use verbs with salient aspectuality to modify the aspectual meaning content of another verb or the representation of a whole state of affairs. The formal means by which this modification could take place was a converb construction, in which the modified main verb figured as the non-finite verb form (the converb). At the end of the grammaticalization process, some of the auxiliaries ended up as suffixes. Within Kamas sources from the middle of the 18th to the beginning of the 20th century, the various degrees of grammaticalization are documented. The relevant grammaticalization processes are semantic reduction, fixation and formal reduction; the first two processes can be understood as prerequisites for the third process which puts an end to the coexistence of grammaticalized and non-grammaticalized items. The main Kamas auxiliaries are listed and, according to their function, grouped into non-transformative vs. initial-, final-, and momentaneous-transformative auxiliaries.
\end{abstract}

In Kamas ${ }^{1}$ sources, one can observe a multi-stage grammaticalization pattern in which full verbs turned into aspectual auxiliaries as a first step, and then into aspectual suffixes. In older sources on Kamas, especially Castrén (1847), most auxiliaries still occur in their full form, cf. also Schiefner (1854). Some 65 years later, Donner (1912/1914) found a few auxiliaries that are better taken to be aspectual suffixes. The use of Kamas aspectual auxiliaries is an instance of code copying from neighbouring Turkic languages, especially Hakas; the further development of suffixalization is an internal development in Kamas. ${ }^{2}$

${ }^{1}$ Kamas is a Southern Samoyed language that was still spoken in the early twentieth century by approximately 50 people on the northern side of the Eastern Sayan Mountains. In Abalakova, their last village, Castrén (1847) and Donner (1912/1914) collected language data. Kamas had been strongly influenced by Turkic languages for centuries but its last speakers shifted to the use of Russian.

2 The Kamas system of auxiliaries replaced an earlier system in which aspect had been marked by endings inherited from Proto-Samoyed. That system can be 
In what follows, the two main steps of that grammaticalization process will be discussed, along with the major auxiliaries and aspectual suffixes, respectively.

1. First, we have to mention the syntactic device that constitutes a link between the auxiliary and the main verb it modifies. This device is known as converb construction involving the general Kamas converb - LAP. Converbs are non-finite verb forms that are in an adverbial relationship with another verb form. The term 'converb' can be replaced by 'adverbial participle', 'gerund', or Russian deeprichastie.

Converb constructions are in principle multifunctional, i.e., their exact meaning depends on context. ${ }^{3}$ In (1), there are two events of which one precedes the other:

(1) šaškan mola? ńergəlü?bijə?

magpie become.cv ${ }^{4}$ fly.inch.past.3pl

'Turning into magpies, they [the ghosts] flew away.' ('After they had turned into magpies, the ghosts flew away.' or 'The ghosts turned into magpies and flew away.')

(Joki 1944, 98: šāškan móлańergu'u'лubi; Klumpp 2002, 120)

found in Selkup, the nearest relative of Kamas. The endings in that system can partly still be found in Kamas, but they ceased to be productive there: e.g., Kamas kan- 'go away': kandə- 'go' = Selkup Taz qen- 'go away' : qenti- 'go', but this imperfective ending, ${ }^{*}-N T$ 2, is never found on any of the numerous Turkic loan verbs found in Kamas (whereas other inherited verbal derivation patterns are productive even on Turkic loan verbs, cf. Klumpp 2002, 47). Aspectual auxiliaries are used in the whole Turkic language family. Similar code copying - without formal reduction, however - occurs in other Uralic-Turkic contact regions, e.g., in the Volga-Kama region in Mari and Udmurt, where the models had been Chuvash and Tatar constructions (cf. Pischlöger 2001 for an overview); Mator aspectual auxiliaries are independent borrowings from Turkic (Helimski 1997, 188). Selkup also has converb constructions whose meaning is aspectual (e.g., Bolzhunovskaya 1998), but the concrete aspectual auxiliary systems of Selkup and Kamas can hardly be seen as common inheritance.

${ }^{3}$ This is formulated by König $(1995,60)$ as follows: "the semantic contribution made by the converb itself to utterance meaning must certainly be analyzed in such a way as to be a suitable basis for all possible interpretations."

${ }^{4}$ Abbreviations: \# = word boundary, aor = aorist, $\mathrm{cv}=$ converb, def $=$ definite conjugation, Gram = grammatical morpheme, inch $=$ inchoative, Lex $=$ lexical morpheme, $\mathrm{mom}=$ momentaneous, $\mathrm{tf}=$ transformative. 
The connection between the two events can often be interpreted as purpose (2) or cause (3):

(2) ijabə ṕele? kambi

mother.acc.3sg search.cv go.away.past

'He left looking for his mother.' ('He left in order to look for his mother.' or 'He left to look for his mother.' or 'He left and looked for his mother.')

(Joki 1944, 197: $i \bar{a} b^{\curvearrowright} p^{‘} e l \varepsilon$ kämbi; Klumpp 2002, 122)

(3) mazərogən măndola? dŭ ne ba?lu?bi bŭssittə smoke-hole.loc see.cv this woman stop.mom.past drink.inf.lat

'Seeing [the man-eater] in the smoke-hole, the woman stopped drinking.' ('Because she saw the man-eater in the smoke-hole, she stopped drinking.')

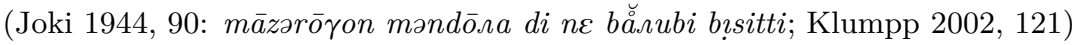

As can be seen in (3), other items may intervene between the converb and the finite verb. According to the unmarked word order, the converb precedes the finite verb, but the inverse order is also possible, as in (4):

(4) măn ej tŭmnem ṕaydəla?

I not know.pres.1sg write.cv

'I cannot write.'

(Joki 1944, 196: man ei təmnem piaydlå; Klumpp 2002, 123)

2.1. The posterior constituent of such a construction can also be an aspectual auxiliary. In that case, word order is not free: the auxiliary invariably follows the converb and no other material can intervene. This phenomenon is referred to by Lehmann $(1995,158)$ as 'fixation', a process whereby 'syntagmatic variability' is reduced.

A frequently occurring auxiliary is $i P b$ ə whose main-verb meaning is 'lie'. The function of that auxiliary is marking imperfective aspect. In the next example (5), coming from Castrén's material, the auxiliary picks one of the two possible meanings of the verb $n u$ (perfective 'stop' and imperfective 'stand').

A purpose or cause reading of this construction, as in (2) and (3), would be highly curious: ' I I stand in order to lie', ?'I stand because I lie'. Its temporal reading, as in (1), would be possible ('I stand, then I lie') but Castrén's gloss 'стою' does not suggest this. We can conclude that the verb 'lie' does not occur here in its original meaning but as an auxiliary (see 2.2. for details on its function). At this stage of grammaticalization, 
(5) nula? iPbəm

stop/stand.cv LIE ${ }^{5}$.aor.1sg

'I am standing.' (Literally: 'I lie standing.')

(Castrén 1847, 115: nula'i’bym; Klumpp 2002, (45a))

it is impossible to decide whether the posterior constituent of the converb construction is an auxiliary or a full verb except on the basis of semantic criteria. This is because formally the two verb forms are not distinct, see (6) where the posterior constituent of the converb construction, $i$ P b 'lie' is a full verb:

(6) tăn kădə mola? i?bəl

you how become.cv lie.aor.2sg

'Why are you lying here?'

(Joki 1944, 99: tăn kådə mo la' ‘’’̀̀л; Klumpp 2002, 68)

It is a widely known phenomenon in grammaticalization research that grammaticalized and non-grammaticalized forms, respectively the old and the new use, survive side by side. This phenomenon is called split by Heine-Reh $(1984,57)$, and divergence by Hopper-Traugott (1993, 11620). ${ }^{6}$

2.2. The function of the auxiliary 'lie' in (5) is to select the imperfective meaning ('stand') of the verb $n u$ 'stop/stand'. It has a similar function in (7) where it is in construction with the verb tuPbda 'row'. That biaspectual stem has two meanings: semelfactive 'perform one stroke' and iterative 'perform several/many strokes'. The auxiliary selects the imperfective (iterative) meaning:

\footnotetext{
${ }^{5}$ SMALL CAPITALS in glosses indicate that the verb occurs here as an auxiliary, rather than in its full meaning.

${ }^{6}$ Unfortunately, the Kamas sources do not give relevant information concerning stress. Still, it seems to be fair to assume that the auxiliary construction had a different stress pattern. At least in Turkic languages, such difference can be found (cf., e.g., Demir 1993, 74).
} 
(7) tu?bla? i?bəm

row.cv LIE.aor.1sg

'I am rowing' (Literally: 'I lie rowing')

(Castrén 1847, 115: thu'bla'i'bym; Klumpp 2002, (46a))

In short, the function of the auxiliary 'lie' is to mark an event as an unbounded situation. The meaning of the verb 'lie', on the other hand, can be described as "a body is positioned on a base such that a larger part of the former touches the latter and it is likely that no change of that position will occur for a while". Of these meaning components, "no change" is important for imperfective aspect. The verb 'lie' can transfer that inherent aspectual property onto the whole event described in the converb construction. Another component of its meaning, "a larger part of the body touches the base" is unimportant, indeed disturbing. In order for the verb 'lie' to turn into an aspectual auxiliary, it is not only required for it to contain the relevant meaning component but also for its nonappropriate meaning components to fade. This can be called semantic reduction. The grammaticalized auxiliary will not be called "semantically reduced verb" but rather "semantically reducible verb" here, given that it may retain some other meaning components unreduced. Schönig (1984) speaks of "full verb meaning transfer" with respect to Tatar auxiliaries; cf. (8) where the meaning 'lie' is not incompatible with the meaning 'sleep' of the main verb, yet Castrén's gloss shows that the verb 'lie' occurs here in its auxiliary role:

(8) kunolla? i?bəm

sleep.cv lie.aor.1sg

'сплю; I am sleeping' (Literally: 'I lie sleeping.')

(Castrén 1847, 186: kunolla'i'bym; Klumpp 2002, (44a)) ${ }^{7}$

2.3. In addition to $i P b ə$ 'lie', the items amnə 'sit', nu 'stand', kandə 'go' and mı̆n 'go' also occur as imperfective auxiliaries, marking durative, fre-

${ }^{7}$ Another example involving the verb sa?ma 'fall' expressing momentaneous aspect is as follows. In the first sentence, the original meaning has completely faded away, whereas in the second, it may have been retained:

(i) tru nükke korola? sa?məbi

'This woman got angry ["fell angry"]' (Joki 1944, 197; Klumpp 2002, (534))

(ii) nuna lăbəla? sa?məbi

'A rocky wall collapsed ["fell collapsing"]' (Joki 1944, 85; Klumpp 2002, (535)) 
quentative, iterative, or habituative aspect readings (aktionsarten). The function of perfective auxiliaries, on the other hand, is to indicate that the event involves a definite change of situation. This can be entering a situation (ingressive and inchoative aktionsarten), leaving a situation (egressive and resultative actionsarten), or crossing both borders at once (momentaneous aktionsart). These three subgroups will be called, following Johanson (1971) and Schönig (1984), initial-transformative, finaltransformative, and momentaneous-transformative, respectively, whereas the imperfective group will be referred to as non-transformative.

Let us mention two examples of the perfective group. The first is the opposite of the imperfective (5) above. Here, the auxiliary kan- whose full verb meaning is 'go away', selects the perfective meaning 'stop' of the biaspectual verb $n u$ - 'stop/stand'.

(9) inet nula? kambi

horse.3sg stop/stand.cv GO.AWAY.past

'His horse stopped.' (Literally: 'His horse went stopping.')

(Joki 1944, 92, inct nuлāmbi; Klumpp 2002, (440a))

Apart from kan-, final-transformative auxiliaries also include šo- 'arrive', kun- 'lead away' and ba?bdə- 'throw away'; initial-transformative auxiliaries are $u$ Pbdə- 'stand up' and kojo- 'stay'. The use of the momentaneoustransformative auxiliary sa?mə- 'fall' can be exemplified as in (10):

(10) Ket't'ün güd'ər [...] uPla? sa?məbi

Ket't'ün güd'ər stand.up.cv FALL.past

'K.g. jumped up.' (Literally: 'K.g. fell standing up.')

(Joki 1944, 95: kett'śün-gud'ur [...] u'la sa'məbi; Klumpp 2002, (532))

3.1. The grammaticalization of some Kamas auxiliaries stopped at the stage at which there is no formal difference between the original main verb and the auxiliary. Other verbs, like 'lie', went through further development whereby they changed not only in their meaning but also in their form. In the case of 'lie', the result of formal reduction is the following $((11 \mathrm{a})=(5))$ : 
(11) (a) nula? iPbəm

stop/stand.cv LIE.aor.1sg

'I am standing.'

(Castrén 1847, 115: nula'i’bym; Klumpp 2002, (45a))

(b) nula?bəm

stand.imperf.aor.1sg

'I am standing.'

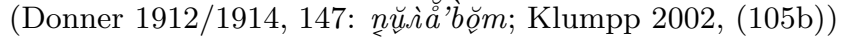

(c) bazo? a?d'əgən nula?bə

again road.loc stand.imperf.aor.1sg

'He is standing on the road again.'

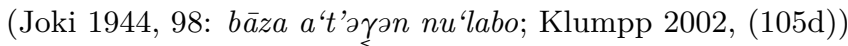

In all three examples, the same derivation is seen, with an important difference. The first example has four syllables and comes from Castrén's material collected in 1847. The second and third examples, however, were recorded by Donner in 1914, and consist of only three syllables. Hence, formal reduction resulted in the diminution of syllable count, a process that initiates what Heine and Reh $(1984,21)$ refer to as erosion: "bisyllabic $>$ monosyllabic $>$ simple consonant/vowel $>$ germination $>$ tonal/ stress rule". Lehmann $(1995,126)$ calls this type of grammaticalization "phonological attrition", the relevant parameter being "integrity". Bybee et al.'s $(1994,19)$ hypothesis says that "semantic reduction is paralleled by phonetic reduction" (emphasis mine, G.K.). In the case of Kamas auxiliaries, as we saw, there are semantically reduced verbs that are formally non-reduced. The converse situation does not arise. Therefore, it is better to say that semantic reduction is a prerequisite for formal reduction.

3.2. Which items undergo formal reduction? It is not the whole auxiliary that changes: only its stem does. But the change does not merely concern the stem of the auxiliary - it also affects the ending of the converb before it.

$$
\begin{array}{llll}
\text { (12) } & \text { nu+lai\# } & \text { ilbə }+\mathrm{m} & \text { nu+laPbə+m } \\
\text { stand }+\mathrm{cv} & \text { lie }+1 \mathrm{sg} & & \text { stand }+\mathrm{LIE}+1 \mathrm{sg} \\
\text { Lex }_{\mathrm{a}}+\text { Gram }_{\mathrm{a}} & \text { Lex }_{\mathrm{b}}+\mathrm{Gram}_{\mathrm{b}}> & \text { Lex }_{\mathrm{a}}+\mathrm{Gram}_{\mathrm{c}}+\mathrm{Gram}_{\mathrm{b}}
\end{array}
$$

More exactly, it is not only the verb 'lie' that is grammaticalized: it is the verb 'lie' and the ending of the converb that are grammatical- 
ized together. Bybee et al.'s (1994, 4-5) definition of grammaticalization reads like this: "...grammaticalization theory begins with the observation that grammatical morphemes develop gradually out of lexical morphemes or combinations of lexical morphemes with lexical or grammatical morphemes" (emphasis added, K.G.).

3.3. Of course, there are some morphosyntactic consequences of this change: one is the loss of word status by the auxiliary. In a converb construction, syntactically, the auxiliary is the main verb, whereas semantically the non-finite verb is the main verb. After formal reduction, the original auxiliary ceases to be a separate word; rather, its stem merges with the converb ending into a new, complex suffix. The change does not extend to other morphological information like tense, person, or number. That information continues to be represented after the segment that used to be the stem of the auxiliary. But the new carrier of that information is now the original non-finite main verb that has turned into a finite verb with the suffix(es) of the former auxiliary, thus becoming a main verb syntactically, too. The rest of the converb ending does not signal word boundary any more but becomes the initial portion of a new, complex suffix. Since all auxiliaries were grammaticalized on the basis of the general $L A$ ?- converb, formal reduction has yielded a new, $L$-initial class of aspectual suffixes. These new aspect markers occupy the position of the inherited valence suffix and the tense/mood suffix in the word, as shown by (13):

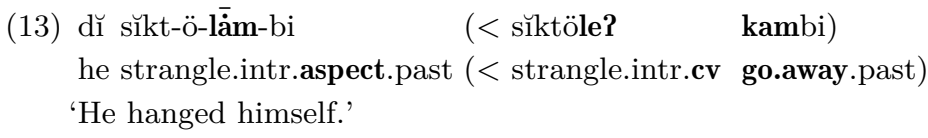

The result of the increase in "coalescence" or "boundedness" (Lehmann 1995, 148), i.e., the suffixalization of the former auxiliary, can be clearly seen from the change of vowel harmony pattern, see (14) where backharmonic amna 'sit' turned front-harmonic as an auxiliary:

(14) dı̌ šüPbdöbi gijən bü bejlemne (< bejle? amna $)$

he wake.up.past where.loc river cross.imperf.aor ( $<$ cross.cv sit.aor)

'He woke up where they cross the river.'

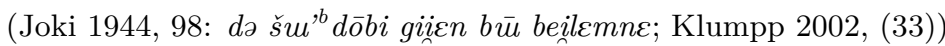


The loss of word status has not only phonological but also syntactic criteria; see (15) where the original intransitive verb amnə- 'sits' is grammaticalized to the extent that it may receive an object-conjugation marker that would have been ungrammatical earlier:

(15) pan tabəndə ularzaydə t'abolamnət (< t'abola? *amnə+t)

tree.gen trunk.loc.3sg sheep.pl.3sg keep.imperf.aor.3sg.def

( $<$ keep.cv sit.aor.3sg.def)

'She is [sitting and] keeping her sheep at the trunk of the tree.'

(Joki 1944, 95: p'an tābəndə, uлārzaydə t'abōлamnəd; Klumpp 2002, (20))

4. Formal reduction includes a number of processes like apocope $-L A$ ? amnə- > -LAmnə-, - LAP uPbdə- > -LUP(bdə)- or consonant loss - LA? kandə- > -LĀndə-, $-L A ?$ baPbdə- > -LA?(bdə)-, cf. the four stages of the reduction of the verb ba?bdə- (in Castrén's and Donner's original notes):

(16) (a) phällebaábdewiäm 'I put it down'

(Castrén, cf. Klumpp 2002, (340))

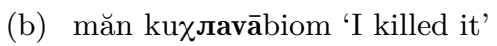

(Donner, cf. Klumpp 2002, (370d))

(c) sublaabdewiam 'I scooped it'

(Castrén, cf. Klumpp 2002, (349))

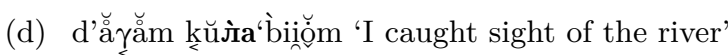

(Donner, cf. Klumpp 2002, (377c))

Table 1 below summarises the results of formal and semantic reduction of twelve Kamas verbs. ${ }^{8}$ In the fifth column, formally reduced formations can be seen. Here (if not earlier) we have to do with a formally and functionally homogeneous paradigm, due to "paradigmaticization" (Lehmann 1995, 135).

5. It becomes clear from the table that the degree of grammaticalization among Kamas auxiliaries is not uniform. In my view, it is unlikely that this has purely phonological reasons: if, for instance, the $k$ of kan-

${ }^{8}$ The number of auxiliaries is even larger; but the other auxiliaries are not listed in the table because they also have directive and other functions in addition to aspectual ones ( $i$ - 'take', $i$ - 'be', $m \breve{\imath-}$ 'give', $\ddot{u} z \partial$ - 'dismount'), or else their function cannot be ascertained due to lack of sufficient data ( $i$ i da- 'hit'). The verb $n u$ 'stand' can be found in the table, although its indirective (evidential) function is also likely to exist: Kamas -LAP $n u$ - is formally equivalent to Turkic - (I)ptIr - < $-(V) p$ turur that is a "marker of indirectivity" (Johanson 2000, 72). 
Table 1

Semantic and formal reduction of Kamas aspectual auxiliaries

\begin{tabular}{|c|c|c|c|c|c|}
\hline 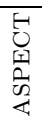 & $\begin{array}{l}\text { ASPECT } \\
\text { READING }\end{array}$ & $\begin{array}{l}\text { AUXILIARY } \\
\text { SUBCLASS }\end{array}$ & $\begin{array}{l}\text { SEMANTICALLY } \\
\text { REDUCIBLE } \\
\text { AUXILIARIES }\end{array}$ & $\begin{array}{c}\text { FORMAL } \\
\text { REDUCTION }\end{array}$ & $\begin{array}{l}\text { DERIVATION > } \\
\text { CONJUGATION }\end{array}$ \\
\hline \multirow{2}{*}{ 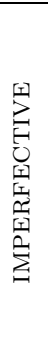 } & \multirow{2}{*}{$\begin{array}{l}\text { Durative, } \\
\text { frequenta- } \\
\text { tive, iterative } \\
\text { and habitive } \\
\text { aktionsarten }\end{array}$} & $\begin{array}{l}\text { Non-trans- } \\
\text { formative } \\
\text { stative } \\
\text { auxiliaries }\end{array}$ & $\begin{array}{l}\text { amnz- 'sit' } \\
\text { iPbə- 'lie' } \\
n u \text {-'stand' }\end{array}$ & $\begin{array}{c}>-L A m n \text { - } \\
>-L A P b ə- \\
-\end{array}$ & $\begin{array}{l}\text { Imperfective } \\
\text { present? }\end{array}$ \\
\hline & & $\begin{array}{l}\text { Non-trans- } \\
\text { formative } \\
\text { dynamic } \\
\text { auxiliaries }\end{array}$ & $\begin{array}{l}\text { kandz- 'go' } \\
\text { minn- 'go' }\end{array}$ & $\begin{array}{c}>-L \bar{A} n d \partial- \\
-\end{array}$ & \\
\hline \multirow{3}{*}{ 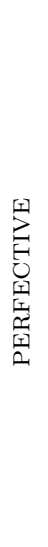 } & $\begin{array}{l}\text { Inchoative } \\
\text { and ingres- } \\
\text { sive aktions- } \\
\text { arten }\end{array}$ & $\begin{array}{l}\text { Initial-trans- } \\
\text { formative } \\
\text { auxiliaries }\end{array}$ & $\begin{array}{l}\text { upbdə- 'stand up' } \\
\text { kojo- 'stay' }\end{array}$ & $>-L U P(b d \partial)-$ & \\
\hline & $\begin{array}{l}\text { Resultative } \\
\text { and egressive } \\
\text { aktionsarten }\end{array}$ & $\begin{array}{l}\text { Final-trans- } \\
\text { formative } \\
\text { auxiliaries }\end{array}$ & $\begin{array}{l}\text { kan- 'go away' } \\
\text { šo- 'arrive' } \\
\text { kun- 'lead away' } \\
\text { baPbdə- } \\
\text { 'throw away' }\end{array}$ & $\begin{array}{c}>-L \bar{A} N- \\
- \\
- \\
>-L A P(b d \partial)-\end{array}$ & \\
\hline & $\begin{array}{l}\text { Momen- } \\
\text { taneous } \\
\text { aktionsart }\end{array}$ & $\begin{array}{l}\text { Momenta- } \\
\text { neous-trans- } \\
\text { formative } \\
\text { auxiliaries }\end{array}$ & sa?mə- 'collapse' & - & \\
\hline
\end{tabular}

can disappear, why that of kun- cannot? Or, if $b$ - can be dropped from $b a P b d$, why is it that $m$ - cannot be dropped from mun? Hence, the question arises whether we have to do with a unitary derivation of aspects at all, or whether there is a correlation between the two stages of grammaticalization and the two functions. In his well-known definition, Kuryłowicz $(1965 / 1975,52)$ points out that "grammaticalization consists in the increase of the range of a morpheme advancing from a lexical to a grammatical or from a less grammatical to a more grammatical status, e.g., from a derivative formant to an inflexional one" (emphasis added, G.K.). The more highly grammaticalized aspectual auxiliary 'lie' occurs very frequently in Kamas texts. Interestingly, it never occurs in 
the past tense, only in unsuffixed aorist. ${ }^{9}$ The Hakas (Turkic) verb for 'lie', čat-, has been grammaticalized to present tense, - $(p) \check{c} A^{10}$ (e.g., Anderson 1998, 25; Johanson 1995, 93). From this, it might be concluded that the suffix -LAPbə- in Castrén's and Donner's sources already corresponded to the present, past, and future markers, and belonged to the paradigm of each verb, e.g., in the case of $n u$ - 'stop/stand':

(17) Present:

nu-ga-m

Imperfective present: nu-la?bə-m

Future: nu-la-m

Past: $\quad$ nu-bja-m

If - $L A P b$ - is indeed a kind of present tense marker, we would expect it to exist in negative forms, as well, given that Hakas present tense also has a negative version (see e.g., Anderson 1998, 45; Baskakov-Borgoyakov $1975,202)$. However, in Kamas sources, $-L A P b ə-$ is not found in negative forms. This may be due to mere chance, but it is also possible that - $L A P b$ ə- is still a marked aspectual form that has no negative counterpart because the aspectual modification concerned is only relevant if the event actually takes place (Klumpp 2001, 124). I think the grammaticalization of - $L A P b$ ə- for present tense was under way when the extinction of Kamas in the first half of the twentieth century put an end to that change.

6. Certain conclusions can be drawn from the grammaticalization of Kamas auxiliaries, even if these are not entirely new insights within grammaticalization research: in order for a lexical item to assume grammatical function, an appropriate meaning component is required (2.2). Its disturbing meaning components may fade away, but its original meaning may also survive (2.2). The semantic reduction of the item undergoing grammaticalization and the fixation of its position within the syntagm (2.1) are prerequisites for formal reduction (3.1). Formal re-

\footnotetext{
${ }^{9}$ It is true that it may also occur in the present or future tenses. In these cases, its function is inchoative-transformative (Klumpp 2002, 202), e.g., 
duction puts an end to the coexistence of grammaticalized and nongrammaticalized item. The deletion of the formal means of grammaticalization (3.2) restores the balance between syntax and semantics (3.3). Formal reduction does not take place in a unitary manner (4) and further grammaticalization can remove certain items from the paradigm of grammaticalized items (5).

To finish with, let us say a few words about the frequency of Kamas aspectual auxiliary constructions. This can be illustrated by Donner's Tale 8 (Joki 1944, 94-9) in which 120 finite verbal predicates are found of which 41 , or $34 \%$, are aspectual converb constructions (Klumpp $2002,330)$. This suggests that aspectual auxiliaries cannot be taken to represent a marginal phenomenon; rather, they must have played a central role in the Kamas verbal system.

\section{References}

Anderson, Gregory D. 1998. Xakas. LINCOM Europa: Languages of the world: Materials 251. LINCOM, Munich \& Newcastle.

Baskakov, Nikolay A.- Mikhail I. Borgoyakov 1975. Грамматика хакаского языка. Наука, Москва.

Bolzhunovskaya, Lyudmila M. 1998. Слособы глагольного действия в диалектах селкупского языка. Автореферат, Новосибирск.

Bybee, Joan - Revere Perkins - William Pagliuca 1994. The evolution of grammar. Tense, aspect and modality in the languages of the world. Chicago University Press, Chicago \& London.

Castrén, Matthias Alexander 1847. Manuscripta Castréniana XIX. Samoiedica 13: Kamass-Samoiedica. University Library, Helsinki.

Demir, Nurettin 1993. Postverbien im Türkeitürkischen (Turcologica 17). Harrassowitz, Wiesbaden.

Donner, Kai 1912/1914. Field notes (dictionary, grammar, texts). Manuscript. Archives of the Finno-Ugric Society, Helsinki.

Heine, Bernd - Mechthild Reh 1984. Grammaticalization and reanalysis in African languages. Buske, Hamburg.

Helimski, Eugene 1997. Die matorische sprache. wörterverzeichnis - grundzüge der grammatik - sprachgeschichte (studia uralo-altaica 41). SZTE Finnugor Tanszék \& MTA Nyelvtudományi Intézet, Szeged \& Budapest.

Hopper, Paul J. - Elisabeth Closs Traugott 1993. Grammaticalization. Cambridge University Press, Cambridge.

Johanson, Lars 1971. Aspekt im Türkischen (Acta Universitatis Upsaliensis/Studia Turcica Upsaliensia 1). Almqvist \& Wiksell, Uppsala. 
Johanson, Lars 1995. Mehrdeutigkeit in der türkischen Verbalkomposition. In: Marcel Erdal-Semih Tezcan (eds): Beläk Bitig. Sprachstudien für Gerhard Dörfer zum 75. Geburtstag (Turcologica 23), 81-101. Harrassowitz, Wiesbaden.

Johanson, Lars 2000. Turkic indirectives. In: Lars Johanson-Bo Utas (eds): Evidentials, 61-87. Mouton de Gruyter, Berlin \& New York.

Joki, Aulis J. (ed.) 1944. Kai Donners Kamassisches Wörterbuch nebst Sprachproben und Hauptzügen der Grammatik (Lexika Societatis Fenno-Ugricae 8). SUS, Helsinki.

Klumpp, Gerson 2001. Alte Negation und neue Tempora im Kamassischen. In: Heiner Eichner (ed.): Fremd und Eigen. Untersuchungen zu Grammatik und Wortschatz des Uralischen und Indogermanischen, in memoriam Hartmut Katz, 115-28. Edition Praesens, Wien.

Klumpp, Gerson 2002. Konverbkonstruktionen im Kamassischen (Veröffentlichungen der Societas Uralo-Altaica 58). Harrassowitz, Wiesbaden.

Kuryłowicz, Jerzy 1965/1975. The evolution of grammatical categories. In: Esquisses linguistiques II, 38-54. Fink, München.

König, Ekkehard 1995. The meaning of converb constructions. In: Ekkehard KönigMartin Haspelmath (eds): Converbs in cross-linguistic perspective. Structure and meaning of adverbial verb forms adverbial participles, gerunds, 57-95. Mouton de Gruyter, Berlin \& New York.

Lehmann, Christian 1995. Thoughts on grammaticalization (LINCOM studies in theoretical linguistics 1). Lincom Europa, München \& Newcastle.

Pischlöger, Christian 2001. Hilfsverbverbindungen in einigen uralischen und nichturalischen Sprachen. In: Tõnu Seilenthal (ed.): Congressus Nonus Internationalis Fenno-Ugristarum, 7-13.8.2000, Tartu. Pars IV, 45-52. University of Tartu, Tartu.

Schiefner, Anton (ed.) 1854. M. Alexander Castréns Grammatik der samojedischen Sprachen. Nordische Reisen und Forschungen. Bd. 7. Academy of Sciences, St. Petersburg. (Reprinted in 1919 by Zentralantiquariat der DDR, Leipzig.).

Schönig, Claus 1984. Hilfsverben im Tatarischen. Untersuchungen zur Funktionsweise einiger Hilfsverbverbindungen. Harrassowitz, Wiesbaden.

Address of the author: Gerson Klumpp

Institut für Finnougristik/Uralistik

Ludwig-Maximilians-Universität München

Ludwigstr. 31

D-80539 München

gersonk@lmu.de

A preliminary version of this paper was presented at the 2003 session of the Budapest Uralic Workshop organised by the Department of Finno-Ugristics of the Research Institute for Linguistics of the Hungarian Academy of Sciences. 